\title{
La categoría de lebenswelt en Juirgen Habermas y sus dificultades ante el diálogo social intercultural ${ }^{1}$
}

\section{The world of life category in Jürgen Haber- mas and its difficulties when confronted with intercultural social dialogue}

Iván Raimundo Canales Valenzuela²

\section{RESUMEN}

Se observa en el continente latinoamericano una recepción del pensamiento habermasiano en la dirección de querer pensar desde él problemas de integración social inherentes a las problemáticas de desigualdad social y política de nuestros pueblos. Nuestra convicción es que a partir del problematismo de la categoría de Lebenswelt, entre otras, dicha empresa no es factible pues hemos podido mostrar importantes exclusiones categoriales en el núcleo duro (heurística negativa) de la teoría de acción comunicativa de Habermas. Esta es la tesis que pretendemos defender en este artículo.

Palabras clave: Integración social, Globalización, ética, comunicación, acción.

\section{ABSTRACT}

Seen in the Latin American continent, the reception of Habermasian thinking in the direction of wanting to think from him, social integration problems inherent in the problems of social and political inequality of our peoples. Our conviction is that from the category problematism of Lebenswelt, inter alia, that enterprise is not feasible, since we have been able to show significant categorical exclusions in the core (negative heuristic) of the theory of communicative action of Habermas. This is the thesis that we argue in this article.

Key words: Integration social, globalization, ethic, comunication, action.

Proyecto de Iniciación en Investigación, Fondecyt $N^{\circ} 11070045$

2 Dr. Iván Raimundo Canales Valenzuela, Dr. en Filosofía, Profesor Adjunto, Departamento de Filosofía Universidad Católica del Maule, Talca, Chile. icanalesv@ucm.cl 


\section{Introducción}

El objetivo de este artículo es reflexionar críticamente sobre el concepto de Lebenswelt al interior de la dialógica habermasiana para valorar las potencialidades y límites de esta teoría para pensar desde ella una integración social intercultural. Tanto nuestra investigación doctoral como nuestro proyecto Fondecyt han explorado minuciosamente sobre el problematismo de esta categoría y de esta dialógica para el objetivo señalado. Por otro lado, se observa en el continente latinoamericano una recepción del pensamiento habermasiano en la dirección de querer pensar desde él problemas de integración social inherentes a las problemáticas de desigualdad social y política de nuestros pueblos. Nuestra convicción es que a partir del problematismo de la categoría de Lebenswelt, entre otras, dicha empresa no es factible pues hemos podido mostrar importantes exclusiones categoriales en el núcleo duro (heurística negativa) de la teoría de acción comunicativa de Habermas. Exclusiones que impiden que la pluralidad de nuestros pueblos puedan ser considerados como legítimos interlocutores del todo social y político, pues socioevolutivamente pertenecen a una pluralidad de mundos de la vida que, la mayor de las veces, no exhiben las competencias dialógicas comunicativas propias de los mundos de la vida postconvencionales o propiamente modernos. Al interior del artículo nos hacemos cargo de todas estas afirmaciones presentando en [1] un planteamiento del problema; en [2] la recepción habermasiana de la categoría husserliana de Lebenswelt; en [3] el concepto de Lebenswelt al interior de la heurística negativa de la teoría de la acción comunicativa de Habermas; en [4] presentamos la Lebenswelt en el diálogo entre modernidad secularizada y tradiciones religiosas e integración social intercultural; en [5] concluimos sobre el resultado de nuestro periplo investigativo; y en [6] ofrecemos una alternativa de comprensión no habermasiana del concepto de Lebenswelt desde la trama social de los pueblos latinoamericanos.

\section{El problema}

En nuestra tesis de doctorado "Ética dialógica y ética praxeológica ante el problema de la integración social”, de 2004, conclui- mos en el nivel metodológico que la "teoría de la acción comunicativa” (TAC) de J. Habermas presenta importantes insuficiencias categoriales frente al desafío de racionalizar éticamente vínculos sociales mundializados. En dicha tesis se precisó bajo qué respectos la ética dialógica habermasiana presenta un marcado carácter etnocentrista. En lo fundamental concluimos que el discurso ético-dialógico de Habermas está fundado en una concepción de la racionalidad tal, que podría ser calificada de categorialmente cerrada a la comprensión de vínculos sociales mundializados. Ello es así porque la hermenéutica habermasiana se sedimenta desde un peculiar concepto de 'mundo de la vida' -que intenta huir de las categorías egológicas de la filosofía de la conciencia- del cual, por un lado, se extraen las categorías lingüístico-pragmático-formales que constituyen la acción comunicativa y, por otro, su estructura es definida como el ámbito o como el único lugar categorial desde el cual se puede acceder a una crítica global de la sociedad. Es decir, el mundo de la vida es substrato sostenedor de categorías, y es categoría a la vez.

En cuanto a su estructura el mundo de la vida se nos presenta como interacción simbólicamente mediada en la cual se realizan la reproducción cultural, la integración social y los procesos de socialización de cada individuo. Desde esta perspectiva, el mundo de la vida queda concebido como 'intersubjetividad lingüística' que determina los distintos ámbitos de acción (teleológico, normativo y dramatúrgico) según los requerimientos de su propia estructura. Es, por tanto, la acción comunicativa la que posibilita una autorreflexión crítica de la totalidad social del mundo de la vida. O de otro modo, es a través de la acción comunicativa que los hablantes pueden reinterpretar al mundo de la vida conscientemente. Pueden, por tanto, referirse al propio mundo objetivo, social y subjetivo, para definir en común una situación cotidiana que ha sido problematizada.

Como contrapartida a los procesos comunicativos de integración social presentes en el mundo de la vida están las diferenciaciones sistémicas que se producen en el proceso evolutivo de toda sociedad, diferenciaciones operadas por el subsistema político y el económico. Para Habermas, estas diferenciaciones 
sistémicas solo pueden ser institucionalizadas si están previamente ancladas en el mundo de la vida. Pero para que ese anclaje sea posible, el mundo de la vida debe haber sido suficientemente racionalizado. Es decir, en él, derecho y moral deben haber alcanzado un estadio postconvencional de racionalidad para que los conflictos puedan ser resueltos comunicativamente. Sin embargo, hemos advertido que esta hermenéutica crítico-comunicativa colapsa cuando intentamos pensar desde ella una sociedad mundial que se articula desde vínculos sociales mundializados. En efecto, con este nuevo orden de realidad caen tanto el núcleo duro de la teoría -porque se trata de mundos de la vida con distintos estadios de evolución social (preconvencional, convencional y postconvencional)- como la estructura de mundo de la vida, puesto que ahora tenemos en él una pluralidad de procesos de socialización y de reproducción cultural en concurrencia.

Por tanto, concluimos que si la "justificación última de la regresión al mundo de la vida es, según Habermas, la intención crítica de su teoría, y si de facto los recursos normativos del mundo de la vida se han diferenciado hasta convertirse en meros subsistemas de la sociedad mundial, cabe preguntarse si una crítica eficaz no tiene que comenzar por reconocer este hecho.

Además, no se ve por qué una crítica a las innovaciones sistémicas del mundo de la vida tiene que tener un carácter avanzado y no más bien conservador ${ }^{3}$. Podemos afirmar después de la detallada revisión del texto habermasiano Theorie des kommunikativen Handelns, que la crítica de A. González es concluyente. Porque ni siquiera la original propuesta habermasiana de una sociología del derecho emancipatoria (1992) puede salvar el hiato que se produce entre mundo de la vida y sistema. Por tanto, toda crítica desde cualquier mundo de la vida se haría desde el impacto del sistema sobre una sociedad particular; quedando, de este modo, siempre pendiente la crítica sobre la totalidad mundial. 0 , de otro modo, para que la crítica habermasiana pudiera validarse, propone González, "habría que esperar a la realidad de un mundo de la vida de alcance mundial para que la crítica pudiera dirigirse al sistema como un todo"4. Por tanto, podría suceder a partir de esta hermenéutica comunicativa habermasiana (dialéctica del mejor argumento, donde todos son legítimos interlocutores), la cual está anclada en un mundo de la vida con un universo simbólico homogéneo y socioevolutivamente postconvencional, que las pretensiones de validez para la comprensión de la sociedad como un todo termine siendo la imposición fáctica de las cosmovisiones de los pueblos más poderosos y no una verdadera justificación racionalmente fundada ${ }^{5}$.

Cabe recordar que Habermas expone en su 'teoría de la acción comunicativa' las propiedades formales que deben poseer las tradiciones culturales para que en el mundo de la vida resulten posibles orientaciones racionales de acción. "Y sobre todo para que estas orientaciones puedan condensarse en un mundo de la vida racional" (J. Habermas, Teoría de la acción comunicativa, Taurus, Madrid, 1998, vol. I, 105). La pregunta es evidente: ¿cómo puede ser pensado desde estas propiedades formales un diálogo simétrico de carácter global si las propiedades formales señaladas son las que corresponden a los mundos de la vida de ciertos países del occidente europeo que supuestamente habrían alcanzado un desarrollo socioevolutivo postconvencional? En este nivel metodológico, dada la pluralidad de universos simbólicos en concurrencia en el contexto de una integración social de carácter global, se puede concluir también que tanto el concepto como la categoría 'mundo de la vida' resultan ser en Habermas enormemente problemáticos para la tarea de conceptuar racional y éticamente vínculos sociales mundializados. O de otro modo: las aporías que presenta el concepto de "mundo de la vida" en la teoría de la acción comunicativa justifica la investigación especial del mismo en el contexto de la totalidad de la obra de Habermas con el objeto de poder determinar los límites

A. González (1994). Un solo Mundo: la relevancia de Zubiri para la teoría social (tesis doctoral), Universidad Pontificia Comillas, Madrid, 53.

4 Loc. cit.

5 Cf. A. González (1997). Estructuras de la praxis: ensayo de una filosofía primera. Trotta, Fundación X. Zubiri, Madrid, 27. 
tanto de su potencialidad crítica como de su potencialidad hermenéutica.

Si bien es cierto hemos sostenido, en nuestra investigación doctoral que no es posible pensar con dicha categoría una integración social y cultural de carácter global, Jovino Pizzi sostiene lo contrario en su texto El mundo de la vida. Husserl y Habermas $(2005)^{6}$. Pues expresamente declara que "el rescate del concepto de Lebenswelt significa la abertura a un razonamiento que no rechaza ni olvida las formas histórico-políticas de la diversidad de mundos y de sus peculiaridades. En efecto, se trata de reconocer las potencialidades de cada cultura, de su memoria histórica y de las evidencias originarias de 'otros' mundos, sin por eso caer en una polarización de una racionalidad unilateral. Quizá esto sea uno de los puntos de partida para la configuración de una filosofía que es, al mismo tiempo, universalista y particularista $y$, así, luchar contra las patologías de una racionalidad negadora de la diferencia"" . Es claro que aquí hay diversos modos o perspectivas para la interpretación de los alcances y límites del concepto de "mundo de la vida" presente en la obra de Habermas. Según Pizzi, sí podemos pensar un diálogo intercultural desde este concepto. Es más habla expresamente de rescate del concepto de Lebenswelt para este objetivo. En su texto El mundo de la vida. Husserl y Habermas, Pizzi comienza su análisis con el concepto de Lebenswelt en Husserl para luego culminar con su recepción crítica por parte de Habermas en Ciencia y técnica como ideología. También en el texto: $O$ conteúdo moral do agir comunicativo encontramos un pormenorizado análisis de cómo este concepto de Lebenswelt es recepcionado por Habermas en Teoría de la acción comunicativa. En ambos análisis Pizzi defiende la relevancia de esta categoría para la actual configuración de un diálogo social de carácter global. Siendo evidente la con- tradicción en las conclusiones de ambas investigaciones (de Canales y Pizzi), ella nos puede permite justificar también, aclarar en el presente artículo, los alcances, posibilidades y límites del concepto de Lebenswelt al interior de la dialógica habermasiana.

\section{Recepción habermasiana de la categoría de Lebenswelt (1970-1971) ${ }^{8}$}

Habermas comienza su análisis crítico respecto del concepto de Lebenswelt en Husserl, afirmando que, a diferencia de Kant, quien analizó un mundo de experiencias posibles teniendo en vista la objetividad o las condiciones subjetivas necesarias del conocimiento, Husserl entendió el ámbito objetual de las ciencias de la naturaleza como un producto artificial derivado que solo puede ser alcanzado, si atendemos a su emergencia, poniendo al descubierto el fundamento de sentido que es el mundo de la vida cotidiana (alltäglichen Lebenswelt). Para Husserl, las ciencias de la naturaleza reciben su suelo nutricio de la transformación de la experiencia cotidiana ya organizada en el mundo de la vida, se trata, por tanto, de una experiencia cotidiana precientífica.

Esta experiencia cotidiana es ante todo relativa al cuerpo y a sus órganos; está cortada (en términos) perspectivistas al talle de un yo con una experiencia de espacio y tiempo centrada en torno al sujeto. Además, la experiencia cotidiana se forma no solo cognitivamente, sino en conexión con actitudes afectivas, intenciones $e$ intervenciones prácticas en el mundo objetivo. (...) Finalmente, la experiencia cotidiana no es un asunto privado: es parte de un mundo compartido intersubjetivamente, en el que cada sujeto vive, habla y actúa en cada caso con los demás sujetos. Esta experiencia intersubjetivamente comunalizada se expresa en sistemas simbólicos,

Jovino Pizzi, El mundo de la vida. Husserl y Habermas, Ediciones Universidad Católica Silva Henríquez, Santiago-Chile, 2005; O conteúdo moral do agir comunicativo, Editora Unisinos, Sao Leopoldo RS Brasil, 2005.

7 J. Pizzi, 2005, op. cit. 179.

8 Hay dos textos complementarios que nos ayudan a clarificar la recepción crítica que Habermas hace del concepto husserliano de Lebenswelt, ambos textos están recogidos en el libro Zur Logia der Soziawissenschanten (1985). El primer artículo se titula "Zur Problematik des Sinnverstehens in den empirischen-analytischen Handlungwissenschaften" (1967). El segundo se titula "Objetivismus in den Sozialwissenschaften" (1977). Ahora bien, los argumentos de ambos artículos están sintetizados en el texto de 1970 / 71 "Vorlesungen zu einer sprachtheoretischen Grundlegung der Soziologie". Es interesante observar cómo la recepción habermasiana del concepto husserlianao de Lebenswelt está ya madura en 1970/71 y es la misma que se presenta en el artículo de 1977 y en el libro de 1981 TAC. 
sobre todo en el sistema simbólico que es lenguaje natural, en el que el saber acumulado está dado al sujeto particular como tradición cultural ${ }^{9}$.

Desde esta perspectiva la propia ciencia es ella misma un objeto cultural más entre otros posibles. Pues se trata de una manifestación vital de sujetos capaces de lenguaje y acción. Por tanto, lo que Kant no logra visualizar, en su crítica del conocimiento, es que las teorías científicas solo son generales en el contexto de una comunidad de conocimiento. $Y$ que, por tanto, tienen que presuponer como algo dado, la validez fáctica de su mundo cotidiano de la vida ${ }^{10}$.

Habermas, siguiendo a Husserl, concluye que herraríamos si eligiéramos como paradigma de la constitución de un mundo de la experiencia posible el ámbito de la constitución meramente objetual de la experiencia (Kant). Pues la constitución del conocimiento científico está anclada en el mundo de la vida, y este mundo de la vida constituye el fundamento de la realidad científicamente objetivada (Husserl) ${ }^{11}$. Por tanto, toda crítica del conocimiento científico y de la naturaleza debe previamente suponer la crítica sistemática de las posibilidades de constitución de un mundo de la vida.

La crítica sobre las condiciones de la experiencia posible no puede ser dirigida desde un concepto de experiencia inherente al quehacer científico (por ejemplo desde la física de Newton), como en el caso de la crítica de Kant. Habermas sostiene que una efectiva crítica del conocimiento comienza no tanto por una crítica trascendental del mismo (Kant), sino, más bien, por una teoría de la constitución del mundo de la vida (Husserl), entendida esta como una teoría de constitución de la sociedad. Para Habermas su "teoría de la acción comunicativa" va a ser el lugar donde debiera quedar satisfecha esta necesidad de fundamentar teóricamente la consti- tución del mundo de la vida o la constitución del todo social.

Para Habermas, otro aporte relevante de la fenomenología de Husserl para la configuración de una teoría social en perspectiva fenomenológica, es el hecho de que este da al concepto de constitución un giro descriptivo que no está presente en Kant. Husserl dirige desde un principio su mirada reflexiva fenomenológica a cómo están dados a la conciencia los objetos sensibles y los objetos categoriales. Sin embargo, el tipo de subjetividad que emerge desde el pensamiento de Husserl no es trascendental como la kantiana (condiciones subjetivas universales y necesarias), sino que genera un horizonte abierto de objetos posibles, que permite una pluralidad de distintos tipos de objetualidad que solo cabe aprehender en términos descriptivos ${ }^{12}$. Para Habermas, el aporte de Husserl, a través de esta estrategia conceptual, reside en que nos abre "al ámbito de una teoría de la constitución de la sociedad, que en actitud descriptiva investiga las estructuras generales del mundo de la vida"13. Desde esta perspectiva el mundo de la vida es concebido fenomenológica y sociológicamente como un mundo constituido por operaciones sintéticas. En las que se reconocen estructuras constituidas por interconexiones de sentido, que los sujetos intersubjetivamente socializados producen una y otra vez, "en la medida en que sus prácticas cotidianas se orientan a objetos susceptibles de experiencia"14. Habermas considera también un tercer aporte relevante de la fenomenología de Husserl para la constitución de una teoría social en perspectiva fenomenológica, a saber, que la reflexión husserliana se plantea desde el plano del yo trascendental particular del observador fenomenológico y no desde el plano de un yo trascendental general y anónimo (Kant). Para Husserl, expresamente lo que hay es una pluralidad de yoes trascendentales, que si prescindimos de la primacía epistemológica que tiene para cada cual su propia

\footnotetext{
Habermas 1984, 36 [1997, 39].

10 Cf. Habermas 1984, 36 [1997, 39].

11 Cf. Habermas 1984, 36 [1997, 40].

12 Cf. loc. cit.

13 Habermas 1984, 38 [1997, 40-41].

14 Habermas 1984, 38 [1997, 41].
} 
subjetividad, solo constituyen el mundo social de la vida mediante las relaciones que entablan unos con otros" ${ }^{15}$. La perspectiva kantiana, sin embargo, nos plantea la imposibilidad de pensar la comunalización de sujetos trascendentales que configuran monádicamente su mundo.

A continuación Habermas nos plantea dos problemas que son esenciales para toda teoría fenomenológica de constitución y generación de la sociedad. A saber: 1. que la relación que toda sociedad articulada y comprendida en términos de interconexiones de sentido guarda una relación inmanente con el problema de la verdad, puesto que toda estructura de sentido tiene pretensiones de validez, que en general son aceptadas en el mundo de la vida, de modo ingenuo o acrítico; 2. que a partir del minucioso análisis de los problemas con que chocan las tentativas fenomenológica de análisis de la intersubjetividad resultará que no tenemos otra opción sino sustituir el primado de la intencionalidad por el primado del entendimiento lingüístico. Estos problemas, según Habermas, no pueden ser solucionados desde la perspectiva de una teoría de la conciencia, sino, solamente podrán ser correctamente abordados desde de una teoría de la comunicación lingüística. Para Habermas es claro que toda interconexión de sentido en el mundo de la vida, tiene pretensiones de validez que deben exhibir sus condiciones de legitimidad a través de un diálogo intersubjetivo. Sin embargo, para Husserl

La verdad puede definirse (...) por referencia al concepto de intención. La verdad es la coincidencia identificadora (acompañada de vivencia evidencia) de aquello que pretendemos en la intención, con el objeto correspondiente intuitivamente dado. Pero, entonces, a la inversa, todas las vivencias intencionales están referidas a la verdad de forma inmanente y necesaria ${ }^{16}$.

Antes de presentar la crítica al concepto de verdad como evidencia que realiza Habermas, queremos subrayar que para este resulta interesante, observar en Husserl, el hecho de que toda intención lleve asociada un "poner", una "posición", y que el mundo de la vida en su conjunto pueda entenderse en términos de una tal posición. "Pues las estructuras de sentido, de las que está constituido el mundo de la vida, solo existen en la pluralidad de pretensiones de validez que le son inherentes" ${ }^{17}$. Se trata por tanto de una corriente de valideces interconectadas que implica necesariamente en sus intenciones un horizonte infinito de valideces no actuales. Donde tanto los actos "dóxicos" (actos que se dirigen a hechos: percepciones, representaciones, recuerdos, juicios) como los no "dóxicos", es decir, actos de la esfera de la afectividad y de la voluntad, implican posiciones provenientes de una intención que anticipa el cumplimiento o no de la autodonación del objeto, lo cual supone, evidentemente, una referencia inmanente a la verdad. Por tanto, el propio mundo de la vida descansa sobre pretensiones de validez creídas, que en principio siempre son susceptibles de problematizarse.

Ahora bien, la "aplicación universal del concepto de intención cumplible en términos intuitivos asegura 'susceptibilidad de verdad' a todas las formas estructuradas en términos de sentido, ya tengan un sentido cognitivo o un sentido primariamente emocional y volitivo"18. Es esta circunstancia de que la vida intencional esté universalmente dirigida a la verdad, lo que va a permitir a Husserl afirmar una absoluta autorresponsabilidad de la humanidad socializada. De este modo, la autorresponsabilidad absoluta se constituye en el correlato subjetivo de una estructura intencional del mundo de la vida en la que, con las posiciones, se anuncia a la vez el interés por mostrar la pretendida legitimidad de tales posiciones. Para Husserl y para Habermas es "carente de responsabilidad la vida, tanto en el plano personal como en el plano político, que se contenta con la facticidad de las pretensiones de validez sin intentar someter a prueba la universal pretensión de verdad del mundo de la vida mediante un esfuerzo filosófico igualmente comprensivo”19. Para Husserl, 
este ideal de un acceso crítico a la totalidad de las pretensiones de validez presentes en el mundo de la vida implica, disciplinarmente, no solo a un cierto proyecto filosófico, sino también a un proyecto político y ético.

Habermas comparte con Husserl la inmanente referencia que un mundo de la vida estructurado en términos de sentido hace a la verdad. Sin embargo, para Habermas dicha referencia le obliga a romper con el marco de una teoría de la conciencia (Husserl), para desarrollar críticamente dicha referencia desde un planteamiento en términos de teoría del lenguaje. Veamos por qué esta opción habermasiana; por qué la necesidad de este distanciamiento crítico respecto de Husserl. Lo primero en subrayar, es el hecho de que Habermas tiene serios reparos con el concepto husserliano de verdad como evidencia, con el concepto de intuición sensible e intuición categorial y con el concepto de intencionalidad. Es a partir de esta crítica que podremos ver cómo va recepcionar Habermas el concepto de mundo de la vida elaborado por Husserl, en general, podemos adelantar que el concepto de Lebenswelt habermasiano va a conservar la estructura formal del concepto husserliano, a saber, que "nos movemos en una corriente de experiencias, juicios, valoraciones y decisiones siempre nuevas (...). Ninguno de estos actos y ni ninguna de las valideces encerrados en ellos, están aislados; implican necesariamente en sus intenciones un horizonte infinito de valideces no actuales, pero que funcionan como tales en esa movilidad en flujo" 20 .

Para realizar el análisis crítico del concepto de verdad como evidencia, Habermas parte señalando que Husserl se ve obligado a levantar el concepto de intuición categorial, precisamente porque concibe la verdad como cumplimiento intuitivo de una intención mediante la presencia directa del objeto intencional. Ahora bien, dicha presencia implica la vivencia de una evidencia. Por tanto, para los objetos categoriales, Husserl necesita postular un tipo de intuición que le es propia, a saber, la intuición categorial. Para Habermas esta estrategia conceptual husserliana no es convincente, porque la argumentación exhibida no es suficiente, quedando más bien la impresión de que la intuición categorial es solo una metáfora de la intuición sensible. Habermas considera necesario realizar aquí una economía conceptual y simplemente postular la generación de objetos catergoriales conforme a reglas ya sean estas matemáticas o gramaticales. Para, de este modo, superar la necesidad de vincular cada categoría a una pretensión de validez que actúa como vivencia de una evidencia ${ }^{21}$.

A estas observaciones Habermas suma su crítica respecto del concepto de "intuición sensible" como autodonación de un objeto. Esto es muy importante, porque es aquí donde Habermas es más agudo respecto de crítica de la verdad como vivencia de evidencia. Según este autor, "en toda intuición, por originaria que sea, entran determinaciones categoriales, toda percepción prepredicativa lleva en sí un excedente hipotético, al que nada de lo actualmente dado puede darle enteramente cobro"22. Desde esta perspectiva habermasiana, todas las percepciones dependen de un marco de interpretación. Es decir, toda experiencia sensible puede problematizarse, debido a que contiene siempre pretensiones de validez hipotéticas que no pueden resolverse en el recurso a percepciones elementales situadas a un nivel más bajo $^{23}$. Para Habermas, al fracasar la estrategia de la verdad como evidencia, debido a la imposibilidad de recurrir a la autodonación del objeto en la intuición, es necesario, entonces, recurrir a una estrategia comunicativa donde los argumentos puedan motivarnos a reconocer o a rechazar la legitimidad de pretensiones de validez problematizadas ${ }^{24}$.

Respecto del concepto de intencionalidad, Habermas nos va a señalar que "existen muy buenas razones para proceder a reformular en términos de teoría del lenguaje ese concepto articulado en términos de teoría de la conciencia, obtenido del modelo de un sujeto

\footnotetext{
Husserl, Crisis 1962, § 40.

Cf. Habermas 1984, 46 [1997, 48].

Habermas 1984, 47 [1997, 48].

Cf. J. Habermas, 1984, 48 [1997, 49].

Cf. loc. cit.
} 
solitario, dirigido a un objeto en actos donadores de sentido"25. Desde esta perspectiva, Habermas está visualizando que el concepto de intencionalidad husserliano tiene más bien un carácter solipsista, o de otro modo, presenta serios déficits dialógicos. Observemos por qué.

Para Habermas, el concepto de intencionalidad debiera ser comprendido comunicativamente, es decir, como el entendimiento de significados de formas simbólicas generadas y empleadas conforme a reglas de corrección semántica o de inteligibilidad. "En el caso paradigmático, estas intenciones van asociadas a oraciones que se emiten en situaciones de entendimiento entre sujetos capaces de lenguaje y de acción"26. Y precisamente es en el contexto de este concepto de intencionalidad que Habermas va a rescatar y valorar la tesis husserliana de la referencia del mundo de la vida estructurado en términos de sentido y de verdad. Es aquí donde se produce el giro habermasiano del concepto de Lebenswelt, pues para Habermas "sentido" y "verdad" en el mundo de la vida, implican a una interconexión de productos simbólicos en el sentido de un entrelazamiento de acciones comunicativas. Donde la facticidad de las pretensiones de validez implicadas en esas manifestaciones es parte esencial de la forma de existencia del mundo de la vida. Ahora bien, para Habermas, tanto el sentido como la verdad o legitimidad de estas pretensiones de validez fácticamente configuradas solo pueden ser mostradas en términos discursivos, es decir, en un discurso fundante, y no desde objetos mostrados en la intuición o desde intenciones ligadas a una posición y autodonación de un objeto de forma inmediata y evidente. Expresamente, Habermas señala que: "en tales posiciones, dóxicas y no dóxicas, se anticipa, no la posibilidad del cumplimiento intuitivo de una intensión, sino la posibilidad de llegar a un consenso sin coacciones acerca de la legitimidad de la pretensión de que se trate"27. De este modo, el mundo de la vida ya no es concebido como lo hace Husserl, a saber, como una corriente de vivencias intencionales, sino más bien, como interconexiones de productos simbólicos o interconexiones de acciones comunicativas.

Para Habermas, esta reconceptualización del mundo de la vida reviste la mayor importancia porque nos permite abordad una problemática que desde Husserl es imposible, a saber, el hecho de que "la universal difusión de pretensiones de validez ingenuamente aceptadas, aproblemáticas, y, sin embargo, no acreditadas, ha sido a lo largo de la historia característica básica de los mundos sociales de la vida"28. Por tanto, necesitamos, según Habermas, "no una reflexión fenomenológica sobre la historia trascendental del nacimiento de un mundo de la vida, sino una tematización, prácticamente cargada de consecuencias, de las pretensiones de validez que hasta entonces lograron sustraerse, no solo de forma contingente, sino de forma sistemática, a un examen discursivo"29. Se trata por tanto de configurar una teoría social que permita explicar superar todo tipo de formación de falsa conciencia en el seno del mundo de la vida. Esto lleva a Habermas a sostener que el mundo de la vida no puede ser concebido desde el primado de la intencionalidad, sino desde el primado del entendimiento discursivo. Pues solo desde aquí es posible resolver los problemas con que chocan las tentativas fenomenológicas de análisis de la intersubjetividad. Es decir, la fenomenología, para Habermas, no puede resolver satisfactoriamente la cuestión de ¿cómo puedo, en tanto que yo trascendental, construir otro yo trascendental y al tiempo experimentar como otro yo precisamente lo en mí constituido? La respuesta a esta pregunta es fundamental para la resolución de la cuestión fenomenológica de la posibilidad de surgimiento de un mundo objetivo, puesto que la objetividad del mundo quiere decir que el mundo está ahí como el mismo mundo para todos los demás, tal como yo lo constituyo para mí.

Para Habermas, las argumentaciones de Husserl sobre el surgimiento de la intersub-

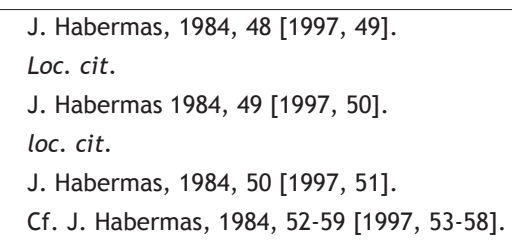


jetividad en la quinta meditación cartesiana es insuficiente puesto que introduce de contrabando una intersubjetividad que no puede deducir bajo los presupuestos de la filosofía de la conciencia ${ }^{30}$. Después de un muy minucioso análisis y crítica de los argumentos de Husserl, Habermas concluye que la:

la exigencia metodológica básica inherente a una filosofía de la conciencia que con la reflexión solitaria parte de las operaciones de la propia subjetividad de quien la esté practicando excluye por principio que los otros constituidos por mí puedan guardar in actu conmigo la misma relación que yo guardo con ellos como objetos intencionales míos. Antes bien, en mi predominio como yo fundante, me veo metodológicamente obligado a afirmarme frente a todos los demás yoes que garantizan la intersubjetividad de mi mundo. Una experiencia comunitarizada intersubjetibamente en sentido estricto no puede pensarse sin el concepto de un sentido comunicado, "compartido" por diversos sujetos. Los significados idénticos no se forman en la estructura intencional de un sujeto solitario situado frente a un mundo ${ }^{31}$.

Con estas consideraciones Habermas intenta mostrarnos cómo un mundo de la vida y una intersubjetividad concebidos desde una filosofía de la conciencia como la fenomenología husserliana, son epistemológicamente impotentes para fundar una teoría social inclusiva donde todos son legítimos interlocutores, a la hora de discutir en el foro público las pretensiones de validez de los saberes de fondo inherentes a la configuración de un mundo de la vida. Es decir, "las teorías de la comunicación gozan de la ventaja de partir de inmediato de la relación intersubjetiva que las teorías de la constitución tratan en vano de deducir a partir de operaciones de conciencia monádica"32. Y por ello acceden a un sentido de la subjetividad auténticamente dialógico donde las relaciones intersubjetivas se piensan conjuntamente con el empleo de expresiones simbólicas por los sujetos capaces de lenguaje y acción.

Para Habermas, son los aportes teóricos de Mead y de Wittgenstein, quienes con los conceptos de "regla" y "rol" introducen en el análisis social, de antemano, la referencia a una relación intersubjetiva o entre sujetos. Por tanto, superan como concepto básico esa conciencia privada, de las filosofías de la conciencia, que solo a posteriori entra en contacto con otras conciencias. Habermas es categórico al respecto, solo las teorías de la comunicación gozan de la ventaja de partir de inmediato de la relación intersubjetiva que las teorías de la constitución tratan en vano de deducir a partir de las operaciones de la conciencia monádica. Nos resta, por tanto, ahora observar cómo concibe Habermas el concepto de Lebenswelt al interior de su teoría de la acción comunicativa para desde allí poder realizar, posteriormente, el balance crítico en relación con las diferencias respecto de Husserl. Ingresemos, entonces, a la heurística negativa de la teoría de la acción comunicativa de Habermas.

3. El concepto de Lebenswelt al interior de la heurística negativa de la teoría de la acción comunicativa de J. Habermas

Para Habermas, el concepto de Lebenswelt opera como el telón de fondo que condiciona y posibilita los encuentros entre actores que se enfrentan a una acción cumunicativodialógica. Se trata de las precomprensiones imbuidas culturalmente que todo proceso de entendimiento presupone. Según Habermas, aquí estamos ante un saber de fondo que permanece aproblemático en su conjunto. Y que solo es tematizado fragmentariamente en la medida en que los hablantes ponen en cuestión un fragmento de mundo como objeto de su interpretación y negociación. En la medida en que este proceso llega a feliz término queda también a disposición de los hablantes "el correspondiente fragmento temático del mundo de la vida (Lebenswelt)"33.

31 J. Habermas, 1984, 58 [1997, 57]; cf. 1985, 202-203, esta última referencia pertenece a un texto de 1967 que aparece en el libro Zur Logik der Sozialwissenschaften (1985). Es importante subrayar que Habermas en este texto extiende también a A. Shütz la crítica que hace al concepto de Lebenswelt de Husserl. El contenido de esta crítica aparece reelaborado nuevamente en el capítulo 4 de la primera parte de TAC vol. I., sin embargo, el contenido argumental de la crítica es exactamente el mismo de la del texto de 1967.

32 Loc. cit.

33 J. Habermas, 1981a, 150 [1998a, 145]. 
Esto es especialmente relevante, porque desde ya Habermas hace funcionar su dispositivo teórico dialógico, bajo la precomprensión de un mundo de la vida común a todos los actores que participan en el proceso interpretativo. Para el proceso dialógico que aquí está en juego, toda definición de una situación constituye una ordenación. Es decir, que los participantes en la interacción a través de su análisis son capaces de identificar las partes o elementos de una situación interaccional cualquiera, y atribuirlas a cada uno de los tres mundos que les corresponda (objetivo, social o subjetivo). La situación actual de acción queda de este modo incorporada al mundo de la vida de los participantes; mundo de la vida que está ya siempre preinterpretado (vorinterpretiert) ${ }^{34}$. También en el caso de divergencias en la definición de la situación, este dispositivo teórico dialógico requiere de un mundo de la vida común a todos los participantes. Pues en situación de divergencias "para ambas partes la tarea de interpretación consiste en incluir en la propia interpretación la interpretación que de la situación hace el otro, de suerte que en la versión revisada su mundo externo y mi mundo externo, sobre el trasfondo de nuestro mundo de la vida, queden relativizados en función del mundo y las definiciones de la situación antes dispares se puedan hacer coincidir suficientemente" 35 .

Nos hemos detenido particularmente en la descripción de esta importante cuestión porque en este texto queda claro que la condición de un mundo de la vida unitario que haga de trasfondo y sea común a todos los participantes, en la teoría habermasiana, es una exigencia categorial inherente a la arquitectura de la teoría. Es decir, que aquí nos encontramos ya con importantes elementos que van a configurar -en palabras de Lakatos- el núcleo duro del programa de investigación. Núcleo que, desde nuestro proyecto de investigación, debe ser analizado e interrogado con el objeto de establecer posibilidades y límites de la propuesta teórica habermasiana para la conceptuación de vínculos sociales mundializados.

En función de dicha interrogación hemos optado por volver sobre el tema de la descentración de las imágenes de mundo que Habermas toma del programa de investigación piagetano. Es decir, estamos ante un procedimiento metodológico por medio del cual Habermas valiéndose de la sociología de la religión de Weber ${ }^{36}$ intenta entender "la evolución de las imágenes religiosas del mundo desde el punto de vista teórico del desarrollo de conceptos formales de mundo, esto es, como procesos de aprendizaje" ${ }^{37}$. Precisamente es a partir de este análisis que Habermas no solo presenta el concepto piagetano de descentración de mundo como la evolución de capacidades cognitivas, sino que también le permite conectar el concepto de acción comunicativa con el de mundo de la vida. Ahora bien, el análisis de dicha conexión será un elemento sustantivo en nuestra exposición, que nos permitirá investigar sobre los alcances y límites de la teoría. Observemos esto ahora con particular atención.

Habermas utiliza el concepto de aprendizaje que Piaget ha elaborado para su comprensión de la ontogénesis de las estructuras de conciencia. Dicho concepto tiene una especial relevancia para Habermas, porque le permite comprender la evolución racional de la sociedad moderna no como la superación de una diversidad de contenidos culturales, sino, más bien, como la emergencia de nuevas estructu-

\section{Cf. loc. cit.}

35 J. Habermas, 1981a, 150 [1998a, 145].

36 Para Habermas, los desarrollos de Max Weber tienen un valor paradigmático, es decir, que del mismo modo que Weber en su análisis sociológico, aborda la cuestión de la conexión entre: cuestión metateórica; cuestión metodológica; y cuestión empírica, concibiendo todos los tipos de acciones sociales como desviaciones del modelo de la acción racional con arreglo a fines, Habermas intenta jerarquizar y clasificar los variados modos de la acción social concibiéndolos como desviaciones de la acción comunicativa. Y todo ello en función de resolver la cuestión empírica del surgimiento del racionalismo occidental o de en qué sentido la modernización de una sociedad puede ser descrita bajo el punto de vista de una racionalización cultural y social (cf. J. Habermas, 1981a, 22-23 [1998a, 22-23]; M. Weber, 1977, 5-92). Con esta nota solo pretendemos aclarar el sentido y la relevancia de la presente exposición.

37 J. Habermas, 1981a, 104 [1998a, 101].

Para Habermas, "Max Weber fue entre los clásicos de la sociología el único que rompió con las premisas de la filosofía de la historia y con los supuestos fundamentales del evolucionismo, sin renunciar, empero, a entender la modernización de la sociedad viejo-europea como resultado de un proceso histórico-universal de racionalización” (J. Habermas, 1981 a, 207 [1998a, 197]; cf. M. Weber, 121993, 209-262). 
ras de las imágenes del mundo, que puede asemejarse al modo como se da la adquisición de nuevos niveles de la capacidad de aprendizaje en los individuos. Procediendo a una aplicación analógica del concepto piagetano de aprendizaje, Habermas puede sostener que:

las cesuras entre la mentalidad mítica, la mentalidad religioso-metafísica y la moderna, se caracterizan por mutaciones en los sistemas de categorías. Las interpretaciones de una etapa superada, cualquiera que sea la textura que tenga en lo que atañe al contenido, quedan categorialmente devaluadas (kategorial entwertet) con el tránsito a la siguiente. No es esta o aquella razón la que ya no convence; es el tipo de razones el que deja ya de convencer ${ }^{38}$.

Se trata, entonces, de empujones devaluadores que parecen (scheinen) guardar relación con las transiciones a nuevos niveles de aprendizaje. A partir de este parecer Habermas sostiene que: con estos empujones devaluadores (Entwertungsschübe) "se transforman las condiciones de aprendizaje en las dimensiones, tanto del pensamiento objetivante, como de las ideas práctico-morales, como de la capacidad de expresión práctico-estética" ${ }^{39}$.

Los desarrollos de Piaget le han servido a Habermas para presentar la diferencia entre aprendizaje de contenidos y aprendizaje de estructuras. Pero también, el programa de investigación piagetano le permitirá a Habermas tener acceso a una nueva conceptuación del desarrollo de las imágenes del mundo, puesto que estas en su integridad también obedecen a niveles en la capacidad de aprendizaje. Se trata, en lo principal, de una progresiva distinción entre mundo interno y externo, a partir de las relaciones que el niño tiene tanto con los objetos como consigo mismo. Ahora bien, si en el mundo externo se distingue la relación que se tiene con los objetos físicos de la que se tiene con los objetos sociales, podemos comprender la emergencia de una diferenciación al interior del mundo externo: como un mundo de cosas perceptibles y manipulables (acción instrumental que vincula la adquisición constructiva del sistema de normas intelectuales), por un lado, y, por otro, un mundo de relaciones interpersonales normativamente reguladas (acción normativamente regulada, que conlleva la inserción del sujeto, por vía constructiva, en el sistema de normas morales socialmente reconocidas). Por tanto, el sujeto se transforma a sí mismo, tanto en su relación con las cosas como con sus relaciones sociales. Particularmente se explicita que toda relación social es "una totalidad en sí que crea nuevas propiedades al transformar al individuo en su estructura mental" ${ }^{40}$. Para Habermas, es particularmente importante el resultado en el que desemboca este análisis. Pues se trata de la construcción de un sistema de referencia para el simultáneo deslinde del mundo objetivo y del mundo social frente al mundo subjetivo. Por tanto, es posible concluir que "la evolución cognitiva significa en términos generales la [sic] decentración de una comprensión del mundo de cuño inicialmente egocéntrico" 41. Para Habermas esta descentración es condición de posibilidad para la formación de un concepto reflexivo de mundo, que permita el surgimiento de esfuerzos comunes de interpretación, o de otro modo, permita una negociación cooperativa de definiciones de la situación. Y ello porque todo acto de entendimiento puede ser comprendido como parte de un proceso cooperativo de interpretación "que tiene como finalidad la obtención de definiciones de la situación que puedan ser intersubjetivamente reconocidas" ${ }^{42}$.

Ahora bien, queremos insistir en la relevancia categorial que este concepto de descentración tiene en la propuesta teórica de Habermas, es decir, es una condición sin la cual el modelo de acción comunicativa, lisa y llanamente, no podría operar. Habermas es enfático en esto, pues en el proceso cooperativo de interpretación:

los conceptos de los tres mundos actúan como un sistema de coordenadas que todos

\footnotetext{
J. Habermas, 1981a, 104 [1998a, 101].

J. Habermas, 1981a, 104 [1998a, 101].

J. Habermas, 1981a, 106 [1998a, 102-103].

Loc. cit.

J. Habermas, 1981a, 107 [1998a, 103].
} 
suponen en común, en que los contextos de la situación pueden ser ordenados de suerte que se alcance un acuerdo acerca de qué es lo que los implicados pueden tratar en cada caso como un hecho o como una norma válida o como una vivencia subjetiva ${ }^{43}$.

Habermas entiende muy bien que este juego libre de interrelaciones de cooperación e interpretación, requiere de un substrato común de referencias que unifique el proceso, porque de lo contrario las interrelaciones desembocarían en un inevitable caos interpretativo. Por ello se ve en la necesidad de introducir, en este lugar, un nuevo elemento categorialmente relevante, se trata del concepto de mundo de la vida (Lebenswelt), concepto que emerge como correlato de los procesos de entendimiento. Es este mundo de la vida el substrato en el cual se sedimentan los esfuerzos interpretativos realizados por las generaciones pasadas. Es decir, que la comunicación entre sujetos no puede sino realizarse en el horizonte del mundo de la vida, el cual opera como trasfondo y fuente "de donde se obtienen las definiciones de la situación que los implicados presuponen como aproblemáticas" ${ }^{44}$. En este medio o substrato realizan los miembros de la comunidad de comunicación la diferenciación entre mundo: objetivo, social y subjetivo. En este lugar ya podemos observar el carácter marcadamente sociológico que tiene el concepto de Lebenswelt habermasiano y cómo esta configuración del mismo dista sustantivamente del proyecto de filosofía primera que pretende articular Husserl a partir de este concepto. Como veremos más adelante, las similitudes conceptuales entre la definición de Habermas y de Husserl al definir el concepto/ categoría de Lebenswelt son mínimas, a saber, en lo principal, coinciden en el nombre, en su carácter de sustrato fundamental o suelo de trasfondo y en la común polémica contra el positivismo moderno.

Lo que ha realizado Habermas en este lugar del texto, con la introducción del concepto de mundo de la vida, es presentar como presupuesto de la arquitectura teórica de su propuesta, la síntesis e indeleble unión que debe haber entre mundo de la vida y acción comunicativa. 0 , de otro modo, la teoría de la acción comunicativa como condiciones formales de interpretación en medio de una comunidad de actores, solo es posible realizarla en el trasfondo de un mundo de la vida que la articule materialmente. De este manera, clarifica Habermas que "los conceptos de mundo y las correspondientes pretensiones de validez constituyen el armazón formal de que los agentes se sirven en su acción comunicativa para afrontar en su mundo de la vida las situaciones que en cada caso se han tornado problemáticas, es decir, aquellas sobre las que se hace menester llegar a un acuerdo" 45 . Es decir, en Habermas es claro que el concepto de Lebenswelt es una categoría metametodológica que permite la unificación y configura un substrato de sentido para la discusión racional de problemas prácticos al interior del todo social, cuestión respecto de cual Husserl declara, expresamente, hacer epojé al momento de tratar sistemáticamente sobre las estructuras del Lebenswelt ${ }^{46}$.

Es relevante también destacar que el nivel de descentración de las imágenes de mundo de los participantes en la comunicación es clave para establecer el nivel de racionalidad crítica con que los actores resuelven sus discrepancias. Es decir, que cuanto más avanzado esté el proceso de descentración de las imágenes de mundo, nos encontramos con una mayor plasticidad estructural en los participantes. Plasticidad que les permitirá acceder a acuerdos alcanzados comunicativamente. A la inversa, cuanto menos avanzado esté el proceso de descentración de las imágenes del mundo, los acuerdos entre los participantes estarán adscritos a interpretaciones del mundo de la vida y a acciones normativamente reguladas.

Habermas es explícito al declarar que, en la medida en que las tradiciones culturales son más primitivas en sus niveles de descentración de las imágenes del mundo, carecerán

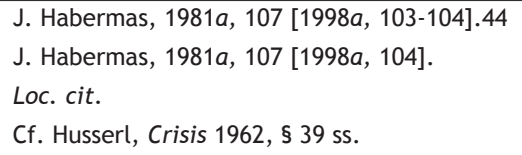


también de las condiciones formales para realizar comunicativamente sus acuerdos:

Cuanto más sean las tradiciones culturales las que de antemano deciden qué pretensiones de validez, cuándo, dónde, en relación con qué, por quién y frente a quién tienen que ser aceptadas, tanto menor será la posibilidad que tienen los propios participantes de hacer explícitas y someter a examen las razones potenciales en que basan sus tomas de postura de aceptación o rechazo ${ }^{47}$.

A Habermas, estos desarrollos le permiten concluir qué condiciones formales deben poseer las tradiciones culturales tanto para la realización de encuentros y consensos racional y comunicativamente fundados, como para la sedimentación de estos acuerdos en un modo de vida racional. Por tanto, a partir de estas consideraciones, para Habermas, emerge un cierto canon (tener que; MuB; o einer schwachen transzendentalen Nötigung ${ }^{48}$ que deben cumplir las tradiciones culturales para posibilitar en el seno de sus mundos de la vida encuentros intersubjetivos comunicativamente articulados. Estrictamente, Habermas habla de propiedades que "deben mostrar" (aufweisen müssen) las tradiciones culturales. $Y$ en la enumeración de estos cuatro "tener que mostrar o poseer" (aufweisen müssen) ocupa el verbo modal müssen (tener que) + Infinitiv (infinitivo): para a) poner a disposición bereitstellen; para b) permitir gestatten; para c) dejarse retroalimentar rückkopeln Lassen; y para d) interpretar interpretieren ${ }^{49}$. Como quiera que se diga, para Habermas las tradiciones culturales, para poder ingresar dentro del ámbito de interrelaciones comunicativamente articuladas, deben cumplir con ciertas condiciones básicas, que en lo principal son dependientes del nivel de descentración de las imágenes del mundo que cada tradición cultural posea. 0 , de otro modo, relaciones interpersonales comunicativamente fundadas, suponen: primero de un mundo de la vida (monocultural) y segundo, que este mundo de la vida se halle en un nivel de descentración de las imágenes de mundo postconvencional, para que el proceso interpretativo y de acuerdos pueda circular por los canales de validez que la teoría ya ha establecido formalmente. Ahora bien, este núcleo duro de la teoría habermasiana nos deja expuestos a innumerables aporías, si las relaciones comunicativamente fundadas tienen que realizarse en un marco de tradiciones culturales compartidas que suponen, a lo menos, más de un mundo de la vida y, además, con distintos niveles de evolución en su proceso de descentración de las imágenes de mundo, entonces ¿cómo se resuelve aquí (en este nuevo orden de realidad social) la comunicación social intersubjetiva a través de un marco categorial que es válido solo para contextos monoculturales postconvencioanles? Queremos aquí, solo enunciar este problema para tratarlo explícitamente en la segunda parte de nuestra investigación.

\section{Lebenswelt, en el dialogo entre moderni- dad secularizada y tradiciones religiosas e integración social intercultural}

Habermas se plantea la interrogante “QQué significa la sociedad postsecular? (2008), en una discusión sobre el islam en Europa”. En este lugar, Habermas discute que las nuevas tendencias sociológicas han de quitar valor a la tesis de la relación entre modernidad y secularización, dados los actuales cambios globales donde el fenómeno religioso sigue teniendo un impacto social, político, económico y cultural a nivel mundial ${ }^{50}$. Habermas tiene plena conciencia de que este es un tema clave y que de hecho pone en entredicho a la heurística negativa de su teoría de la acción comunicativa. Pese a la importante bibliografía que discute sobre esta tesis, Habermas sostiene que "los defensores de la tesis de la secularización siguen teniendo aún las espaldas bien cubiertas por los datos comparativos globales" ${ }^{51}$. Según nuestro autor, el problema con la tesis de la secularización reside más

\footnotetext{
47 J. Habermas, 1981a, 108 [1998a, 105]. Sería interesante contrastar estas afirmaciones de Habermas con la organización civil y política de los mapuches del sur de Chile a la llegada de los españoles. Cf. el texto de José Bengoa (20072), Historia de los antiguos mapuches del sur. Santiago de Chile: Catalonia.

48 Cf. J. Habermas, 1992, 18 [22000, 66].

49 Cf. J. Habermas, 1981a, 109 [1998a, 105-106].

50 J. Habermas [2009, 64-67].

51 Idem [67].
} 
bien en las conclusiones indiferenciadas, que revelan un uso poco preciso de conceptos como secularización y modernización ${ }^{52}$. Antes de entrar a explicar en qué consiste este "uso poco preciso", insiste Habermas, argumentando a favor de la tesis de la secularización, en que seguiría

siendo cierta la afirmación de que las iglesias y las comunidades religiosas se han ido limitando de una forma creciente, en el curso de los sistemas de diferenciación de los sistemas funcionales sociales, a la función nuclear de la praxis de la cura de almas, teniendo que abandonar sus amplias competencias en otros ámbitos de la sociedad ${ }^{53}$.

Por tanto, la funcionalidad social de la religión resulta ser individual y privada. Esta es exactamente la tesis que Habermas sustenta y defiende en Theorie des komunikativen Handelns (1981). Como sea, Habermas en el siguiente párrafo reconoce la debilidad de esta tesis afirmando que si es posible hablar y pensar hoy día en una sociedad postsecular en Europa, debido a la supervivencia tanto de colectivos religiosos en un entorno que se sigue secularizando continuamente, como al hecho de que efectivamente la pérdida de función y la individualización de la religión no ha tenido como consecuencia la pérdida de su relevancia en el espacio público político o cultural, ni en la conducción de la vida personal. Es en el contexto de este factum aporético (¿por qué podemos denominar como postseculares a sociedades ampliamente secularizadas ${ }^{54}$ ) para la teoría de la acción comunicativa, que Habermas intentará precisar el sentido y alcance actuales de la teoría de la secularización y de su relación con la modernidad.

Dos cuestiones distingue Habermas para abordar esta problemática. La primera es que desde la perspectiva del observador sociológico en las sociedades postsecularizadas, la religión mantiene su relevancia pública y pierde, por tanto, terreno la certeza secularista de que en un proceso de modernización acelerada la religión debería desaparecer a escala mundial. Sin embargo, desde la perspectiva del los participantes en la interacción el dilema y el desafío reside en la interrogante de

¿cómo debemos entendernos a nosotros mismos, en nuestra condición de miembros de una sociedad postsecular, y qué tenemos que esperar unos de otros para que en nuestros Estados nacionales, históricamente bien estructurados, se siga observando una civilidad en el trato de los ciudadanos entre sí incluso bajo circunstancias donde domina una cultura y una cosmovisión plurales? ${ }^{25}$.

Es muy interesante observar cómo $\mathrm{Ha}$ bermas se hará cargo de la cuestión del pluralismo cosmovisional en el contexto de mundos de la vida postseculares. ¿Podrá seguir sosteniendo Habermas su concepto de mundo de la vida pragmática-formalmente o su common sense ilustrado democrático? Y si lo logra, ¿cuál será el costo? Observemos, atentamente, sus argumentos.

El punto de partida de la argumentación de Habermas reside en la problemática de la separación entre Iglesia y Estado y en los costosos logros de una libertad religiosa inclusiva, igual de válida para todos los ciudadanos ${ }^{56}$. Ahora bien, "el Estado constitucional solo puede garantizar a los ciudadanos la misma libertad de religión para todos siempre que no se sigan atrincherando en los mundos cerrados de sus comunidades religiosas respectivas y aislándose

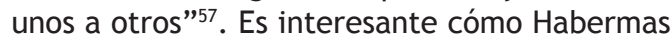
identifica rápidamente lo religioso y el fenómeno social religioso con cuestiones de intolerancia, violencia y guerra fratricida. Esta vez para hablar de la separación entre Iglesia y Estado y de las libertades religiosas trae a colación las guerras de religión en Europa de los siglos XVI y XVII. Implícitamente, Habermas percibe a la religión y lo religioso, siempre como una ame-

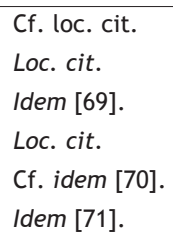


naza en el contexto de una modernidad secularizada. De hecho, en todos sus textos Habermas nunca ha considerado a las religiones como interlocutores legítimos. En Glauben und Wissen les impone condiciones dialógicas postconvencionales para ser legítimos interlocutores en el foro público, condiciones que, ya lo hemos visto en los textos anteriores, son formas camufladas de exclusión social. Precisamente, porque no se ha pensado sistemáticamente qué es el pluralismo religioso en el contexto de una sociedad secular, cuáles son las relaciones de encuentro y reconciliación, modernidad secular y pluralidad religiosa que deben instaurarse en la sociedad mundial, en qué consiste o debe consistir la cooperación que debe haber entre modernidad secular y pluralidad religiosa, para la consecución de la paz mundial.

Habermas observa muy bien cuál es el dilema que deben resolver las sociedades europeas postseculares, a saber, cómo conjugar y mantener la igualdad ciudadana y la diferencia cultural complementándose de un modo justo ${ }^{58}$. Nuestra interrogante es: si la dialógica discursiva habermasiana es instrumento inclusivo privilegiado para lograr esta pacífica integración de ciudadanía democrática y pluralidad cultural. Nuestra convicción es que no solo las creencias religiosas deben revisar sus modos de asistir a este diálogo, también debe hacerlo la sociedad moderna secularizada, pues sus concepto de nación, Estado de derecho, democracia, ciudadanía, poder político, económico, cultura, integración social, son todos problemáticos respecto de la posibilidad de pensar sistemáticamente una integración social de carácter global. La pregunta legítima es la siguiente: ¿cómo y por qué una teoría social y política y una teoría de la comunicación social diseñadas para pensar los problemas de legitimación democrática en las sociedades tardocapitalistas europeas configuradas en Estados nacionales, y con mundos de la vida homogéneos, debiera servir para pensar una integración social intercultural o de carácter global? ¿No hay aquí una enorme asimetría en los términos de la cual la obra de Habermas no se hace cargo? 0 de otro modo, ¿es plausiblemente intercultural el pensamiento de
Habermas? A partir de los textos revisados podemos decir, con convicción, de que no lo es. Porque la pluralidad de diálogos que deben ser pensados, a saber, pluralidad de mundos de la vida, pluralidad cosmovisional religiosa y secular, etc., sobrepasa con creces el estrecho y excluyente marco categorial de la teoría de la acción comunicativa.

Volvamos al texto de Habermas, en las páginas siguientes son analizadas las perspectivas comunitaristas y liberales sobre integración social intercultural, aparece también la defensa apasionada de la ilustración y su principio universal de libertades públicas y los multiculturalistas enemigos de la ilustración. Se trata de todo un marco aporético de la discusión donde los recursos cognitivos esgrimidos hacen crisis.

Es muy interesante observar lo que declara Habermas como conclusión de este debate en el punto 5) del artículo.

\begin{abstract}
Aunque desde un punto de vista empírico se acepte como correcta la caracterización de sociedades "postseculares" referidas a las sociedades de Occidente europeo, se puede estar convencido, por razones filosóficas, de que las comunidades de creyentes deben el influjo que siguen ejerciendo únicamente a la tenaz supervivencia -explicable en términos sociológicos- de forma de pensamiento premodernas ${ }^{59}$.
\end{abstract}

Esta afirmación no es solo convicción de los secularistas, es también convicción de Habermas. Esto es muy importante de subrayar porque de esta afirmación viene una consecuencia lógica ineludible al interior de la dialógica habermasiana, a saber, que si las tradiciones religiosas quieren ser legítimos interlocutores al interior de Estados democráticos de derecho deben acceder a competencias dialógicas de carácter postconvencional. Por tanto, las tradiciones religiosas, en palabras de Habermas, "deben hacer suya, acogiéndola dentro de las premisas de su propia fe, la legitimación secular de la comunidad estatal" ${ }^{60}$. Es interesante subrayar el hecho de que Haber-

\footnotetext{
$58 \quad$ Idem [73].

$59 \quad$ Idem [77].

60 Idem [78].
} 
mas cita como ejemplo a la Iglesia católica, la cual "no se declaró partidaria del liberalismo y de la democracia hasta el Concilio Vaticano II en 1965". En esta argumentación Habermas nada dice de la colaboración que debe haber entre secularización y creencias religiosas. ¿En qué momento las creencias religiosas hacen su legítima crítica de la sociedad moderna secularizada, la cual también exhibe notables déficits éticos y morales; y también importantes déficits de sustentabilidad social, económica, política y cultural en la idea de progreso, desarrollo y gestión de las libertades y de los criterios de equidad social y de respeto a la vida y a la buena vida? Recordemos que esto ya se lo hizo ver el cardenal Ratzinger a Habermas el año 2004 en debate sobre el diálogo entre razón secular y fe en la Academia Católica de Baviera. Donde, a nuestro entender, la postura filosófica de Habermas dejó muy pocos espacios para la consecución de un diálogo fructífero. Y donde Ratzinger, para favorecer el diálogo, tuvo la gentileza de bajar su concepto de "ley natural". Nuestra convicción a la luz de los textos revisados es que la categoría y concepto de mundo de la vida pragmática formalmente configurado por competencias dialógicas postconvencionales (common sense ilustrado democráticamente) son un obstáculo insalvable en vistas de la consecución de un diálogo democrático intercultural.

Expresamente Habermas señala que lo que se requiere es de un cambio de mentalidad que consiste en un proceso de aprendizaje. Ahora bien, "como proceso de aprendizaje solo aparece desde la perspectiva de una autocomprensión secular de la modernidad" 61 , es decir, los procesos de aprendizaje sostenidos son inherentes a la autocomprensión que la modernidad tiene de sí misma, pero no lo son en las tradiciones religiosas. El problema para Habermas es que los procesos de aprendizaje pueden ser promovidos, pero no exigidos moral o jurídicamente, por tanto, la sociedad secular no puede exigir estos procesos de aprendizaje a las tradiciones religiosas, produciéndose entonces con ello, a los ojos de nuestro autor, una gran asimetría dialógica, que va en desmedro de la sociedad moderna secularizada.

Es importante observar aquí que Habermas tiene la sensibilidad suficiente para sostener que de parte del lado de la secularidad se requiere de un proceso de aprendizaje complementario. Sin embargo, es el tradicionalismo religioso premoderno, socioevolutivamente inferior el que tiene que elevarse a un estándar dialógico moderno o postconvencinal; en cambio el aprendizaje del lado de la secularidad implica mirar hacia lo inferior socioevolutivo (las tradiciones religiosas, es decir, "aquellos que no pueden ser tomados en serio como contemporáneos modernos"62) para observar posibles "contenidos semánticos, y acaso tácitas intuiciones propias, que puedan ser traducidos y alojados en una argumentación a nivel público"63. Es interesante observar cómo Habermas jamás pone en cuestión los presupuestos socioevolutivos desde los cuales configura su teoría social y política. Presupuestos socioevolutivos no justificados y que generan asimetrías dialógicas como la recién descrita. Según Habermas, es en el contexto de este diferencial entre lo premoderno y lo moderno, lo convencional y lo postconvencional que el secularismo se ve en apuros, pues los participantes en la interacción se ven ante "la expectativa de que los ciudadanos seculares deban encontrarse en la sociedad civil y en el espacio público con sus conciudadanos creyentes en su condición de tales en un mismo plano de igualdad" 64 , habiendo de hecho radicales asimetrías. Ahora bien, establecidas las asimetrías y las dificultades, señala Habermas que "si todo ha de ir bien, ambas partes deberán, cada una desde su perspectiva, dejarse conducir a una interpretación de la relación entre la fe y el saber que posibilite una coexistencia autorreflexiva y clarificada de las dos" ${ }^{65}$. Es necesario aquí escuchar atentamente la expresión "cada una desde su perspectiva", a saber, las tradiciones religiosas desde la elevación hacia.... la secularización desde su abajamiento hacia... ¿Es esta una razonable propuesta de diálogo intercultural? 
5. Conclusión: dialógica habermasiana y diálogo intercultural

Finalizando este largo periplo, podemos concluir que aquello por lo que se hace especialmente problemática la teoría social habermasiana, a la hora de intentar conceptuar vínculos sociales mundializados, es tanto su teoría de la racionalidad como su particular estructuración y apreciación del concepto mundo de la vida. Respecto de lo primero, hemos explicitado detalladamente el núcleo duro categorial de la teoría. Es decir, que desde los presupuestos de la pragmática formal lingüística habermasiana se estructura un principio y una teoría del discurso, que nos ofrece - para una fundamentación de una teoría de la sociedad- un marco categorial rígido y jerárquico presentado como tabla de doce categorías del entendimiento posible, donde la categoría de mayor jerarquía evolutiva (postconvencional) es la forma moderna de entendimiento. Es esta categoría la que le permite a Habermas formular una teoría de la modernidad, como proceso evolutivo de racionalización; proceso que culmina con el advenimiento de la racionalidad comunicativa. De otro modo, el proceso consiste el liberar en el mundo de la vida progresivamente los potenciales comunicativos de la razón, encapsulados en formas preconvencionales y convencionales del entendimiento. Por tanto, solo un mundo de la vida que ha devenido en racionalidad postconvencional, podrá acceder a un proceso de integración social auténticamente comunicativo o discursivo.

Podemos concluir, entonces, que nuestra hipótesis de trabajo, a saber, la crítica de A. González a J. Habermas, se ha confirmado a través de la revisión de los textos. Sin embargo, cabe recordar que nuestra presentación del pensamiento de Habermas está integramente articulada desde nuestro objeto de investigación, es decir, desde la posibilidad de conceptuar racional y éticamente vínculos sociales multiculturales en una sociedad mundializada. Por tanto, nuestro análisis crítico vale para esta legítima y unilateral perspectiva. Desde ella hemos podido observar cómo el marco categorial de la propuesta de Habermas puede ser caracterizado como de puertas cerradas para la conceptuación de vínculos sociales multiculturales. $Y$ cómo el posterior giro jurídico de la teoría no ha hecho más que confirmar ese cierre. Ello es así fundamentalmente por la clausura categorial que se produce en el núcleo duro de la teoría, pero también porque el referente fáctico de la misma son los problemas de legitimación de una realidad social tardocapitalista, que hoy día ha sido superada por una nueva onda larga expansiva del desarrollo capitalista (globalización sistémica). Nuestro interés, por tanto, radica en poder establecer un marco categorial racional que posibilite abrir puertas categoriales para acceder a una racionalización crítica de una sociedad mundial, a la cual le toca vivir hoy muy dramáticos problemas de integración social y política. Creemos que es posible pensar filosóficamente en un diálogo respetuoso y responsable, a pesar de las -muchas vecesinsalvables asimetrías que el nuevo orden mundial implica. 0 de otro modo, la torre de Babel es un factum, que presenta enormes dificultades para una pacífica convivencia entre los pueblos, por tanto, debe ser posible pensar hoy una convivencia reconciliada en su interior. Se trata, por tanto, como diría Jaspers, "de que la tolerancia militante pueda ocupar el lugar de la brutalidad armada"66. Es desde esta perspectiva que nuestro siguiente paso será exponer qué puertas se abren filosóficamente para fundar racional y éticamente un diálogo entre las culturas. Entre otras, el de Alejandro Moreno es un sugerente programa de investigación, que comentamos, brevemente, en nuestro próximo apartado.

\section{Lebenswelt desde la trama social de los pueblos latinoamericanos}

En vista del diálogo y la integración intercultural deseada, se anuncia la inevitabilidad y necesidad de otra episteme, pues hay muchos mundo de la vida y con pluralidad de configuraciones socioevolutivas, no reductibles a los patrones categoriales de la modernidad, ni de la dialógica habermasiana. Baste mirar en nuestro continente la pluralidad de pueblos originarios, los que configuran lógicas culturales y de integración social, radicalmente distintas de las meramente "modernas". Sin embargo, dichos mundos de la vida han sido

E6 En J. Habermas, ${ }^{2} 1997$ [1999, 40]. 
relegados al mundo inhumano de la barbarie, por todo el sistema-mundo moderno.

Para Alejandro Moreno, la familia es una instancia privilegiada para configurar desde ella el mundo de la vida de la barriada venezolana. Moreno observa - desde su compartir la vida cotidiana en el barrio (in-viviendo) (cf. Moreno et al., 1998, pp. 11 ss.)que las relaciones afectivas, tanto en el seno de la familia como en la estructuración de la comunidad, en sus formas de agrupación, en la manera de manejar los intercambios, etc., juegan un papel central y peculiar, en la dinámica de las interacciones cotidianas, al interior del mundo popular (cf. Moreno, 2006, p. 12). Es esta experiencia lo que obliga a Moreno a replantearse desde la más profunda entraña lo que ya, intuitivamente, había cuestionado en teoría y lo que nunca había pensado cuestionar (cf. Moreno, 2006, p. 13), a saber, el marco conceptual y espistemológico con el cual se pueda acceder adecuadamente a la compresión y diálogo con una realidad social popular tan radicalmente otra como la del barrio venezolano ${ }^{67}$. Por tanto, la pregunta de Moreno es por las categorías racionales necesarias para comprender, interpretar y dialogar con el mundo de la vida cotidiana de la barriada en la que vive y a la cual asiste pastoralmente. Pues las dificultades en la comunicación son muy fuertes, el lenguaje se revela pronto como ilusorio y, por tanto, constituye más bien un instrumento de incomunicación que de comunicación ${ }^{68}$. Es la trama de la afectividad popular lo que revela a nuestro autor las insospechadas raíces del mundo que les daba vida, y revela también las raíces epistemológicas del propio Moreno, las cuales han entrado en crisis al querer intentar, desde ellas, comprender, interpretar y dialogar con la vida cotidiana del barrio. A través de la siguiente cita ilustramos la magnitud y alcance de las problemáticas y aporías racionales que Moreno debe enfrentar para comprender e interpretar adecuadamente la realidad del cotidiano mundo popular:
Comprendí entonces, cuál era el abismo que separaba mi ciencia y mis métodos de la realidad a la que con ellos pretendía llegar. Ni las reformas cualitativas, ni los cambios de paradigma, tipo Capra (1985) o de M. Martínez (1989), ni las apuestas epistemológicas de Ferrarotti, tendían un puente sobre él (p. 14).

De este modo, llega a comprender Moreno que "dentro de la vida que vivía, debían existir, in nuce, posibles categoría y reglas para elaborar un conocimiento que fuera el apalabramiento de esa vida desde ella misma. Comprender exigía pensar desde adentro". (Moreno et al., 1998, p. 12). De otro modo, Moreno nos muestra que entre el aro o el círculo sistémico de la modernidad y la trama vivencial de los mundos de vida cotidiana populares, hay un hiato o un abismo que no es fácil de conceptualizar ni de salvar con las categorías racionales propias de la modernidad y de la postmodernidad filosófica occidental.

Es por ello que para Moreno las fuentes de la comprensión se encuentran en el discurrir de la vida, en su practicación. Estas fuentes están ubicadas en el registro sistemático del vivimiento de las personas, se trata del registro sistemático de la experiencia que se conoce como "historias-de-vida". La elaboración de estas historias de vida requiere de una implicación previa de confianza, la mutua implicación y comunicación desde sus propias claves. Es decir, el espacio dialógico con su radical peculiaridad en cada caso se abre desde en con-vivir y desde el in-vivir la vida del otro. De lo contrario en el lenguaje formalizado de la dialógica moderna, de hecho, el otro nunca aparece, nunca emerge. Los otros populares y marginales, solo aparecen como un problema social, conceptualizados desde categorías sociales que son de suyo excluyente, como las de la dialógica habermasiana.

Alejandro Moreno nos ofrece en sus textos el esbozo de una metodología para la comprensión de un Lebenswelt donde pueda

\footnotetext{
67 Las palabras en Moreno de otro capital texto pueden ilustrar más cabalmente esta cuestión: “Al principio fue una investigación externa, desde categorías para mí incuestionables, con métodos científicamente validados. Elaboraba, ciertamente, un conocimiento sobre la realidad pero me daba cuenta de que ese conocimiento está regido por estructuras cognoscitivas previas y ajenas a esa realidad. Así conocía pero no comprendía” (Moreno et al., 1998, 12).

68 "Me encontré dividido: intelectualmente pensaba de una manera y en la practicación de la vida actuaba de otra. En esta me entendía con la gente del barrio. El conocimiento, en cambio, marchaba por su cuenta" (loc. cit)
} 
emerger cristalinamente la radical alteridad de lo otro, en el mundo-de-vida-popular.

Mediado por el apalabramiento y la interpretación-comprensión, tiene abierto el camino al autoconocimiento y a la reorientación de su propia historia mientras muestra su sentido al mundo exterior exigiendo de este reconocimiento y aceptación de su distinción. Así nuestro trabajo desemboca, por su mismo acontecer, por solo hecho de hacerse y hacerse así, en una propuesta transformadora y liberadora de nuestro pueblo al proclamar su presencia y exigir la respuesta ética69.

Ahora bien, si relacionamos nuestro análisis sobre la categoría de Lebenswelt en Habermas con lo planteado por Alejandro Moreno, podemos concluir con una crucial pregunta: ¿cómo es posible al interior de este marco conceptual habermasiano que Pedro Luis Luna (Moreno et al., 2002) y Felicia Valera (Moreno et al., 1998) puedan ser interlocutores efectivamente válidos, si el concepto de acción comunicativa habermasiano implica solo a actos de habla explícitos? (cf. Habermas, 1984, p. 353 [1997, p. 299]). O de otro modo: ¿cómo Pedro y Felicia pueden ser considerados como interlocutores válidos en medio de categorías procedimentales pragmáticasformales-lingüísticas propias de mundos de la vida socioevolutivamente postconvencionales? No cabe duda de que la trama de la realidad popular estudiada sistemáticamente por Moreno, plantea graves interrogantes epistemológicas a la heurística negativa de la "teoría de la acción comunicativa” de J. Habermas.

Lo relevante de los desarrollos de Moreno es que más allá de nuestra crítica habermasiana, aquí nos encontramos con una reflexión sistemática sobre los mundo-de-vida latinoamericanos, que da cuenta de radical heterogeneidad y pluralidad a través del compartir, del in-vivir y del relatar las experiencias de vida de estos grupos. Surge así una episteme popular, una episteme de la relación como experiencia-practicación originaria y raigal, desde la que brota toda otra praxis y experiencia en la que tiene realidad. Estamos, entonces, ante una epistema que conoce no por individuo, sino por relaciones, las cuales se configuran como fundamento de todo conocer ${ }^{70}$.

No podemos ahondar más en esta interesante cuestión, sin embargo, podemos concluir que Alejandro Moreno nos ha abierto las puertas hacia una nueva comprensión del mundo-de-vida, al cual al menos nos deja abierta también las puertas para pensar sistemáticamente un diálogo radicalmente plural, un diálogo entre lo radicalmente heterogéneo, como lo son la pluralidad de culturas que habitan la Tierra.

\section{Bibliografía}

CANALES, I. (2004), Ética dialógica y ética praxeológica ante el problema de la integración social (tesis doctoral). Madrid: Pontificia Universidad Comillas de Madrid.

GONZÁLEZ, A. (1994), Un solo Mundo: la relevancia de Zubiri para la teoría social (tesis doctoral). Madrid: Universidad Pontificia Comillas.

(1997) ESTRACTURAS de la praxis: ensayo de una filosofía primera. Madrid: Trotta, Fundación X. Zubiri.

HABERMAS, J. (1968). Erkenntnis und Interesse. Frankfurt am Main: Suhrkamp Verlag (21973).

(1968A) PROTESTBEWEGUNG und Hochschulreform. Frankfurt am Main: Suhrkamp Verlag.

(1969). TECHNIK und Wissenschaft als "Ideologie". Frankfurt am Main: Suhrkamp Verlag.

(1971). THEORIE und Praxis: Sozialphilosophische Studien. . Frankfurt am Main: Suhrkamp Verlag ( $\left.{ }^{6} 1993\right)$.

(1973) LEGITIMATIONSPROBLEME im Spätkapitalismus. Frankfurt am Main: Suhrkamp Verlag.

(1976A). ZUR Rekonstruktion des historischen Materialismus. Frankfurt am Main: Suhrkamp Verlag ( $\left.{ }^{6} 1995\right)$.

99 Moreno et al., 1998, 13-14.

70 Cf. Moreno 2006, pp. 243 ss. 
(1976B). “¿WAS heisst Universalpragmatik?” en: J. Habermas, 1984, 299-368; y en

K. O. Apel, 1982, 174-272.

(1981). PHILOSOPHISCHE-POLITISCHE Profile. Frankfurt am Main: Suhrkamp Verlag (Perfiles filosófico-políticos. Madrid: Taurus, 2000).

(1981A). THEORIE des kommunikativen Handelns. Band I. Handlungsrationalität und gesellschaftliche Rationalisierung. Frankfurt am Main: Suhrkamp Verlag, 31999 [Teoría de la Acción Comunicativa: racionalidad de la acción y racionalización social. Madrid: Taurus, 1998a, vol. I].

(1981B). THEORIE des kommunikativen Handelns. Band II. Zur Kritik der

FUNKTIONALISTISCHEN VERNUNFT. Frankfurt am Main: Suhrkamp Verlag, 31999 [Teoría de la Acción Comunicativa: crítica de la razón funcionalista. Madrid: Taurus, 1998b, vol. II].

(1984). VORSTUDIEN und Ergänzungen zur Theorie des kommunikativen Handelns. Frankfurt am Main: Suhrkamp Verlag [Teoría de la Acción Comunicativa: complementos y estudios previos. Madrid: Catedra, colecc. Teorema, 1997].

(1985) ZUR Logik der Socialwissenchaften, Frankfurt am Main: Suhrkamp Verlag.

(1991). TEXTE und Kontexte. Frankfurt am Main: Suhrkamp Verlag, 21992 (Textos y contextos. Barcelona: Ariel, 1996).

(1991A). ERLÄUTERUNGEN zur Diskursethik. Frankfur am Main: Suhrkamp Verlag (Aclaraciones a la ética del discurso. Madrid: Trotta, 2000)

(1991B). ESCRITOS sobre moralidad y eticidad. Barcelona: Paidós.

(1992) FAKTIZITÄT und Geltung. Beiträge zur Diskurstheorie des Rechts und des demokratischen Rechtsstaats. Frankfurt am Main: Suhrkamp Verlag, 51997 (Facticidad y Validez. Sobre el derecho y el Estado democrático de derecho en términos de teoría del discurso. Madrid: Trotta, $\left.{ }^{2} 2000\right)$.

(1996). DIE Einbeziehung des Anderen. Studien zur politischen Theorie. Frankfurt am Main: Suhrkamp Verlag (La inclusión del otro.
Estudios de teoría política. Barcelona: Paidós, 1999).

(21997). VOM sinnlichen Eindruck zum symbolischen Ausdruck. Philosophische Essays. Frankfurt am Main: Suhrkamp Verlag (Fragmentos filosófico-teológicos. De la impresión sensible a la expresión simbólica. Madrid: Trotta, 1999).

(1998). DIE postnationale Konstellation: politische Essays. Frankfurt am Main: Suhrkamp Verlag (La constelación posnacional. Ensayos políticos. Barcelona: Paidós, 2000).

(1999). WAHRHEIT und Rechtfertigung. Frankfurt am Main: Suhrkamp Verlag (Verdad y justitficación. Madrid: Trotta, 2002).

(2001) KOMMUNIKATIVES Handeln und detranszendentalisierte Vernunft. Stuttgart: Philipp Rclam jun (Acción comunicativa y razón sin transcendencia. Barcelona: Piadós, 2003).

(2001A). ISRAEL o Atenas. Ensayos sobre religión, teología y racionalidad. Madrid: Trotta.

(32001B). MÁS allá del Estado nacional. Madrid: Trotta.

(2001C) GLAUBEN und Wissen. Frankfur am Main: Suhrkamp Verlag (en: (El futuro de la naturaleza humana. ¿Hacia una eugenesia liberal? Barcelona: Paidós, 2002).

(2001D) ZEIT der Übergänge. Frankfur am Main: Suhrkamp Verlag (Tiempo de transiciones. Madrid: Trotta, 2004).

(2001E) DIE Zukunft der menschlichen Natur. Auf dem Weg zu einer liberlen Eugenik? Frankfur am Main: Suhrkamp Verlag (El futuro de la naturaleza humana. ¿Hacia una eugenesia liberal? Barcelona: Paidós, 2002)

(2004). DER gespaltene Westen. Frankfurt am Main: Suhrkamp Verlag (El Occidente escindido. Madrid, Trotta, 2006).

(2005). ZWISCHEN Naturalismus und Religión. Frankfur am Main: Suhrkamp Verlag (Entre naturalismo y religion. Barcelona: Paidós, 2006).

(2006) “¡AY Europa!”. en ¡Ay, Europa! Pequeños escritos políticos XI. Madrid: Trotta, 2009. 
HUSSERL, EDMUND (1962), Die Krisis der europäischen Wissenschaften und die

TRANSZENDENTALE PHÄNOMENOLOGIE. Haag: Martinus Nijhoff. [La crisis de las ciencias europeas y la fenomenología transcendental. Barcelona: Crítica, 1991].

MORENO et al. (1998). Historia-de-vida de Felicia Valera. Caracas, Con ocit.

(2006). Buscando al padre. Historia de vida de Pedro Luis Luna. Valencia-Venezuela, Universidad de Carabobo.
MORENO, A. (2006), El aro y la trama. Episteme, modernidad y pueblo. Santiago-Chile, Eds. Universidad Católica Silva Henríquez.

PIZZI, J. (2005a), El mundo de la vida. Husserl y Habermas. Santiago-Chile: Ediciones Universidad Católica Silva Henríquez.

(2005B). O conteúdo moral do agir comunicativo. São Leopoldo RS Brasil: Editora Unisinos. 